\title{
Symbolism---The Main Artistic Style of Katherine Anne Porter's Short Stories
}

\author{
Ru Wang \\ Foreign Language Department, Harbin Medical University \\ 194 Xuefu Road, Nangang District, Harbin 150081, China \\ Tel: 86-451-8667-4598Ｅ-mail: huopingcheng@163.com
}

\begin{abstract}
The paper takes Katherine Anne Porter's Two short stories: "Flowering Judas", "The Grave" as objects of study. It will try to analyze Porter's writing style through her imaginary conception, vivid psychological description and multiple symbolisms so that we can understand her studies and her attitudes to female psychological world and life.
\end{abstract}

Keywords: Symbol, Symbolism, Katherine Anne Porter

\section{Porter and Symbolism}

Symbolism is an art movement which rejected the purely visual realism of the Impressionists, and the rationality of the Industrial Age, in order to depict the symbols of ideas. Influenced by Romanticism and the Preraphaelite Brotherhood, it thrived in France in the late nineteenth century, its influence spreading throughout much of Europe. Rather than the precise equivalents of ideas or emotions, its symbols were meant to be more mysterious, ambiguous suggestions of meanings.

A symbol is something concrete that represents or stands for something else, usually intangible concept idea. It can be an action, a sound, a thing, a movement. It must be seen, heard, felt, tasted, or touched. Certainty of something concrete used as symbolism is often somewhat ambiguous, but they may be frequent repetition, or an appearance of it at a pivotal moment, or a prominent place. A conventional symbol is a symbol that has an understood or widely accepted interpretation. The heart, for example, is a conventional symbol of love. A literary symbol is a symbol that has a possibility of multiple interpretations. For example, water could be used in the same story as both a redemptive and destructive force.

Symbolism is a prominent element in many of Katherine Anne Porter's short stories. According to Porter : symbolism happens of its own self and it comes out of something so deep in your own consciousness and your own experience that I don't think that most writers are at all conscious of their use of symbols. I never am until I see them. They come of themselves because they belong to me, and have meaning to me, but they come of themselves. I have no way of explaining them.... and I suppose you don't invent symbolism.

\section{Symbolism in "The Grave", "Flowering Judas" and "Theft"}

\subsection{Symbolism in "The Grave"}

\subsubsection{Dove.}

In "The Grave", while Miranda and Paul are hunting in the fields, they decide to stop and explore the empty graves that once were the family burial ground. In one of the graves, Miranda finds a screwhead for a coffin, a small silver dove with spread wings and a neat fan-shaped tail, which she rapidly exchanges to Paul for a gold ring. Here, many different views exist concerning the symbolic status of the silver dove. M.A.Grubbs describes the dove as a symbol of innocence, love and peace, and proposes that the dove's emergence from the grave suggests innocence born from experience. According to Joan Givner, the dove shaped like the dove of Venus, is a symbol of earthly love. Another view is that the silver dove symbolizes the past, the mythic, and the sacred. In my point of view, the silver dove, which came from the grandfather's old grave, might symbolize the peace he found in death; The dove is also something they were hunting for. Paul longs to have the dove, which typifies the killing for Paul, the archetypal male as hunter; The imperfect dove also signifies Paul, and his innocence, for he already seemed to be knowledgeable of birth and life; The dove possibly could be merely a personal symbol for Miranda, her youth, and the day she lost a bit of her conventional innocence and many thing such that.

\subsubsection{Paul and Miranda}

Paul shows that he knows more than Miranda about the business of death by telling her it was a coffin screw. But Miranda doesn't care; she's happy with the gold ring she got which is still too big to fit a finger, but fits her thumb nicely. Miranda is more concerned with her future as a female, growing up to wear more feminine clothes like her older sister Maria and avoiding the scorn of the corn cob pipe smoking crones who criticize the unisex 
work clothes her father provides for her. Paul is the possessor of knowledge of death and Miranda possesses dreams of her mature feminine future. Porter uses archetypal symbols freely here.

\subsubsection{The grave}

Death is above and beyond us and all around us and usually out of our control. A grave is something man made. When Miranda and Paul first come upon the old cemetery, the grass is uncropped but sweet smelling, it is neglected yet pleasant. The graves are there yet not there. A grave without a coffin is just a hole in the ground. The grave is death. But the rabbit is life. As the graves provided treasure for the children, they began to kill and skin the pregnant rabbit. Miranda, "excited but not frightened," exclaims "I do not want the skin..., I won't have it." "Paul buried the young rabbits again in their mother's body, wrapped the skin around her, carried her to a clump of sage bushes, and hid her away," then returned to swear Miranda to secrecy. Cycle of life in the story appears when the reader sees at least two graves---the literal grave and the rabbit. Both graves produce treasure; both contribute in some obscure fashion to the last scene of the story. But it must always be remembered that the rabbit is simultaneously a symbol of generation and life.

\subsubsection{The theme}

As a story moves along, readers can see a simple powerful story of two children's contact with mysteries of life and death. Graves provide treasure for children---- a silver dove and a gold ring, but they don't feel comfortable after they got a treasure, the garden is not theirs anymore. In the short and really simple story, Porter depicted children and their reactions on things through symbolism like life and death. This theme and cycle of life have influenced Miranda through the years.

\subsection{Symbolism in "Flowering Judas"}

\subsubsection{Braggioni and Laura}

The two main characters of Katherine Anne Porter's "Flowering Judas", Laura and Braggioni, attempt to fulfill an ideal: they want to have self-fulfillment but also to be integrated into a social society. Neither of the two, however, succeeds in meeting this ideal. Braggioni, as his name suggests his nature, appears to be concerned primarily with pleasure. Even just a physical description shows his extravagant self-indulgence. His "expensive garments" consist of a "lavender collar," a "purple necktie, held by a diamond hoop," a leather belt "worked in silver, glassy yellow shoes...mauve silk hose." Braggioni's extravagant clothing projects how he "loves himself with such tenderness and amplitude and eternal charity". Material possessions both confirm and enhance Braggioni's self-fulfillment and self-worth. Being a vain man, he demands the best for himself; gratifying himself gives him pleasure. Laura, on the other hand, is not only integrated, but also embraced and accepted by the society that rejects Braggioni. Everything that Laura does applies to the order of the society that she lives in. Like Braggioni, Laura's physical appearance is evidence of her compliance to society. Her "hairpins" and "long tight sleeves" indicate that Laura's demeanor is one of regulation. Laura's actions: teach English to Indian children, attend union meetings, visit prisoners "of her own political faith," act as a messenger for these prisoners, warn men in hiding if they are in danger... are what determine her integration. Though these gain Laura a respected place in society, she still suffers from a lack of self-fulfillment. Laura has a rigid principle about right and wrong, about social duty, that keeps her from experiencing pleasure.

Therefore, these two characters, Braggioni----a leader of the Mexican revolution, and Laura---- a young American who is both a revolutionary and a teacher, symbolize ideological opposites: Braggioni's corruption and selfishness versus Laura's honestly and altruism. Both are driven by fear, a fear of betrayal as well as a fear of intimacy. Ultimately, both betray the very principles they claim to uphold.

\subsubsection{Judas Tree}

As the reader experiences the concluding part of the story, certain moral and human ideas begin to emerge with greater clarity. Laura sees the horrifying meaning of her life in the nightmare quality of the final dream scene. She clung to the branch of the Judas tree. The tree's name originated from the belief that Judas Iscariot, the betrayer of Christ, hanged himself on one of them. Laura ate the warm bleeding flowers which symbolize her betrayal of her own spirit and of humanity. She has not possessed either feeling or trust for the people around her, the most unpardonable sin. She says no to everything and everyone. Lacking religious faith and reverence for humanity, Laura will not partake of the body and blood of Christ, symbolizing atonement and salvation. She understands the frightening realization. Porter has not only made the reader feel the full impact of Laura's nightmarish dream, but also has given a fuller understanding of the desperate complications of her mind.

\subsection{Symbolism in "Theft"}

The setting for "Theft" is New York City. The heroine is a writer and reviewer, like Miss Porter. The time is the onset of the Great Depression of the 1930s. The stolen purse in the story symbolizes all property. Appropriately, 
it is made of gold cloth. Thus, the stealing of the purse represents the conflict between the "haves" and "have-nots." But the conflict is never simple in Miss Porter's stories, nor is it easy to arrive at a facile definition of the problem. The young woman who owns the purse has little else. She is in fact close to starving and may really be poorer than the janitress. But, like the purse, she is a symbol of those who possess things other people do not have but want. And at the end of the story, by a brilliant reversal, the janitress has succeeded in making the heroine feel that she has stolen, if not from the janitress herself, then from the janitress' niece. The emotions running through this story are mixed, as are the sympathies of the reader.

\section{Conclusion}

In Porter's stories, she frequently used symbols to express themes of rebellion and loss of innocence, and these themes are evident in "The Grave". It suggests the movement from innocence to knowledge, from the innocence of the dove (which is one of the objects found in the grave), to the gold ring (which is Miranda's sign for the luxury of her own femininity), and to the dead mother rabbit (the mystery of birth and death). Miranda comes to be aware of the decay and death. Particularly in "The Grave", Porter demanded her readers to use the process of remembering and comparing in order to understand the meaning of certain events in the story. Some years later, standing again in the blazing sunshine, Miranda seemed to see her brother, again twelve years old, smiling in his eyes, turning the silver over and over in his hand. The memory "Leaps from its burial place." $\left(C S, \mathrm{p}_{84}\right)$ And the initial vision of death, the dead rabbit which she had long ago chosen, she sees now in its true colors. That dreadful vision of death now gives way to that long ago day's other vision of death, her unchanged brother holding the silver dove.

Porter also used symbols to express her betrayal theme. In "Flowering Judas", Laura feels betrayed by her revolution that doesn't fulfill the early idealistic aims of the movement. Laura also betrays the revolution's ideal by stepping into a church to pray, knowing that discovery will cause a scandal. If she feels betrayed by the church that promised something that Laura has not found, she also betrays her religion, which promises spiritual life, by replacing it with the revolution that practices death. It is too symbolic to say that Laura betrays Eugenio by providing the drugs that makes his suicide possible, but she does betray herself, and in a way that includes her responsibility to Eugenio. Laura has done so partly in unconscious self-protection because she knows that only as long as she is a virgin will she be safe among Braggioni and others, who honor the ideal of chastity in their inherited chivalric code.

Porter was not a prolific writer, but she focused on the social ideology and reflected the loneliness, depression and bewilderment of the westerners. Though she came to nowhere in her spiritual journey, she had created a rich spiritual world for us. Her keen sense of the times and observation, and her active involvement in the social affairs has set good examples for us.

\section{References}

Anne Porter. (1970). Collected Essays and Occasional Writing of Katherine Anne Porter, New York:Delacorte Press

Booz, Elisabeth. (1982). A brief Introduction to Modern American Literature. Shanghai: Foreign Language Education Press, 1919-1980 (Lectures1-30).

Glenway Westcott. (1962). Images of Truth, New York: Harper and Row Press

Hendrick, Willene and George Hendrick. (1988). Katherine Anne Porter Boston: Twayne Press.

Jodi L.Allison-Bunnell, Ruth M. Alvarez etc. (1998). Guide to the Papers of Katherine Anne Porter, Maryland: University of Maryland Libraries.

Katherine Anne Porter. (1985). The Collected Stories, New York: Virago Press.

Libermann, M.M. (1971). Katherine Anne Porter's Fiction, Detroit: Wayne State University Press.

Rubin, Louis Decimus. (1961). Recent southern Fiction: A Panel Discussion Macon, Georgia: Wesleyan College Press

Unrue, Darlene Harbour. (1997). Critical Essays on Katherine Anne Porter, New York: G.K.Hall and Company

Unrue, Darlene Harbour. (1985). Truth and Vision in Katherine Anne Porter's Fiction, Georgia: The University of Georgia Press

Virginia Spencer Carr. (1965). "Background to the Flowering Judas", Porter interviewed with Barbara Thompson for Writers at Work in 1965, New York: New York Press.

W.James. (1890). The Theory of Psychology, New York: New York Press.

Whit Burnett and B.C. Hoffman. (1942). This Is My Best, New York: Dial Press. 